\title{
PENGARUH MODEL PEMBELAJARAN SAINS TEKNOLOGI MASYARAKAT (STM) TERHADAP KEMAMPUAN PEMAHAMAN KONSEP SISWA PADA POKOK BAHASAN EKOSISTEM KELAS VII MTS PARADIGMA PALEMBANG
}

\author{
Amilda $^{1}$, Sulton Nawawi ${ }^{2}$, Uci Minasari ${ }^{3}$ \\ ${ }^{1}$ Dosen Prodi Pendidikan PIAUD Fakultas Tarbiyah dan Keguruan UIN Raden Fatah \\ Palembang \\ Jl. Prof. K.H. Zainal Abidin Fikri No. 1 A KM 3,5, Palembang 30126, Indonesia \\ ${ }^{2}$ Program Studi Pendidikan Biologi FKIP Universitas Muhammadiyah Palembang \\ ${ }^{3}$ Mahasiswa Prodi Pendidikan Biologi Fakultas Tarbiyah dan Keguruan UIN Raden Fatah \\ Palembang \\ Jl. Prof. K.H. Zainal Abidin Fikri No. 1 A KM 3,5, Palembang 30126, Indonesia \\ email: \\ ${ }^{2}$ sulton_nawawi@um-palembang.ac.id \\ ${ }^{3}$ uci.minasari11@gmail.com \\ Telp: \\ ${ }^{2}+6285789933439$ \\ ${ }^{3}+6285832484133$
}

\begin{abstract}
The purpose of the study was to determine the effect of the application of learning model of Science Technology Society (STS) to the ability of understanding the concept of Biology students on the subject of VII grade ecosystem MTs Paradigma Palembang. The desain of study used the design of the Nonequivalent Control Group Design with Quasi Experimental method (quasi experiment). These sample included 35 students. Based on the results of the analysis of students' concept of understanding shows that the implementation of learning using the model of learning Science Technology Society (STS) is better than the conventional learning model. It can can be seen from the calculation of the t-test showed of students' concept of understanding sig t-value $0.000<0,05$, then Ha accepted and $\mathrm{H} 0$ rejected. The result of analysis of the improvement of the average completeness of the conceptual understanding of the experimental class is $48.2 \%$ while the students 'understanding of the control class is $29.2 \%$, which means that the students' understanding of the concept of the experimental class is higher than the understanding of the concept of the control class. This, it can be concluded that the learning model of Science Technology Society (STS) around effect on understanding the concept of students of class VII MTs Paradigma Palembang.
\end{abstract}

Keywords: STM learning model; Understanding Concept of Student.

\section{PENDAHULUAN}

Pendidikan merupakan usaha manusia untuk membina kepribadian sesuai dengan nilai-nilai di dalam masyarakat dan kebudayaan (Hasbullah, 2013). Pada Abad 21 ini kita ditantang untuk mampu menciptakan tata-pendidikan yang dapat ikut menghasilkan sumber daya pemikir yang mampu ikut membangun tatanan sosial dan ekonomi serta sadar pengetahuan sebagai layaknya warga dunia di Abad-21 (Mukminan, 2014).

Namun, menurut Al-Tabany (2015), masalah utama dalam pembelajaran pada pendidikan formal (sekolah) dewasa ini yakni masih rendahnya daya serap peserta didik. Hal ini tampak dari rerata hasil 
belajar peserta didik yang senantiasa masih sangat memperihatinkan.

Pemahaman konsep memiliki peranan penting dalam proses belajar mengajar dan merupakan dasar dalam mencapai hasil belajar. Menurut Samarabawa (2013), faktor penunjang yang dapat dipakai sebagai acuan prestasi belajar seorang siswa adalah melalui pemahaman konsep. Pemahaman konsep sangat penting dengan tujuan agar siswa dapat mengingat konsep-konsep yang mereka pelajari lebih lama, sehingga proses belajar akan menjadi lebih bermakna.

Konsep merupakan suatu hal yang sangat penting, namun bukan terletak pada konsep itu sendiri, melainkan terletak pada bagaimana konsep itu dipahami oleh subjek didik. Pentingnya pemahaman konsep dalam proses belajar mengajar sangat mempengaruhi sikap, keputusan, dan cara-cara memecahkan masalah (AlTabany, 2015).

Namun kenyataan di lapangan, dalam belajar siswa dihadapkan dengan sejumlah materi yang harus dihafalkan tanpa diberi kesempatan untuk memaknai materi yang dipelajari, sehingga siswa banyak belajar tetapi kurang mampu memberi makna belajar. Kondisi inilah yang menyebabkan rendahnya kemampuan pemahaman konsep.

Rendahnya pemahaman konsep terjadi di MTs Paradigma Palembang. Hal tersebut dapat ditunjukkan dengan hasil tes awal yang diberikan pada siswa kelas VII MTs Paradigma Palembang yang terdiri dari 14 soal uraian dengan indikator pemahaman konsep. Berdasarkan hasil yang diperoleh dapat diketahui bahwa pemahaman konsep siswa masih dibawah Kreteria Ketuntasan Minimum (KKM) yang ditetapkan sekolah yaitu 75. Adapun hasil tes yang diperoleh yaitu kelas VIIA dengan nilai rata-rata 50, kelas VIIB dengan nilai rata-rata 44, kels VIIC dengan nilai rata-rata 53, dan VIID dengan nilai rata-rata 48.

Penggunaan model pembelajaran yang tepat, merupakan suatu alternatif untuk mengatasi masalah rendahnya daya serap siswa terhadap pelajaran Biologi.
Setiap model pembelajaran harus sesuai untuk mencapai suatu tujuan tertentu. Jadi untuk tujuan yang berbeda guru harus menggunakan teknik penyajian yang berbeda untuk mencapai tujuan pembelajarannya. Salah satu model pembelajaran yang sesuai untuk meningkatkan kemampuan pemahaman konsep siswa ialah model pembelajaran tipe Sains Teknologi Masyarakat (STM).

\section{Model Pembelajaran STM}

Sains Teknologi Masyarakat (STM) merupakan terjemahan dari Science Technology Society (STS). Pada awalnya istilah Science Technology Society (STS) dikemukakan oleh John Ziman pada tahun 1980 dalam bukunya yang berjudul Teaching and Learning. Ziman mencoba mengungkapkan harapan bahwa konsepkonsep dan proses-proses sains yang diajarkan di sekolah harus sesuai dengan konteks sosial dan relevan dengan kehidupan sehari-hari (Poedjiadi, 2010).

STM berarti melibatkan peserta didik dalam pengalaman, pertanyaan, dan isu-isu yang berkaitan dengan kehidupan mereka. Situasi yang dicari akan melibatkan siswa. Guru berusaha menciptakan situasi di mana siswa akan memerlukan konsep dasar dan keterampilan proses untuk kebutuhan mereka di masa depan. STM memberdayakan siswa dengan keterampilan yang memungkinkan mereka untuk menjadi aktif, warga yang bertanggung jawab dengan menanggapi isu-isu yang dalam kehidupan mereka. Pengalaman dengan ilmu pengetahuan dalam format STM menciptakan warga melek ilmiah untuk menghadapi abad 21(Yager, 1992).

Dalam penelitian ini model pembelajaran STM yang digunakan adalah model pembelajaran yang dikembangkan oleh Poedjiadi (2010), dengan sintaks sebagai berikut, fase 1 (tahap invitasi); fase 2 (tahap pembentukan konsep); fase 3 (tahap aplikasi konsep atau penyelesaian masalah); fase 4 (tahap pemantapan konsep); fase 5 (tahap penilaian). Melalui sintaks model pembelajaran STM siswa dimungkinkan dapat menumbuhkan pemahaman konsep. 


\section{Pemahaman Konsep}

Pemahaman konsep sangat penting dengan tujuan agar siswa dapat mengingat konsep-konsep yang mereka pelajari lebih lama, sehingga proses belajar akan menjadi lebih bermakna (Setiawan $d k k, 2013$ ).

Menurut Bloom yang dikembangkan oleh Anderson dan Krathwohl (2015), indikator pemahaman konsep meliputi, kemampuan Menafsirkan (interprenting), Memberikan contoh (exemplifying), Mengklasifikasikan (classifying), Meringkas (summarizing), Menarik inferensi (inferring), Membandingkan (comparing) dan Menjelaskan (explaining).

\section{METODE PENELITIAN \\ Waktu dan Tempat Penelitian}

Penelitian ini dilakukan pada Kamis, 29 April - Sabtu, 13 Mei 2017, bertempat di MTs Paradigma Palembang.

\section{Jenis Penelitian}

Bentuk penelitian ini ialah penelitian quasi eksperiment design.

\section{Rancangan Penelitian}

Rancangan penelitian ini merupakan proses yang dilaksanakan mulai dari perencanaan, pelaksanaan sampai mengumpulkan hasil olahan data sebagai hasil akhir penelitian. Bentuk desain penelitian yang digunakan ialah Nonequivalent Control Group Design.

\section{Variabel Penelitian}

Pada penelitian ini yang menjadi variabel bebas (X) ialah model pembelajaran Sains Teknologi Masyarakat (STM), sedangkan variabel terikat (Y), yaitu pemahaman konsep siswa.

\section{Populasi dan sampel}

Populasi yang diteliti pada penelitian ini ialah seluruh siswa kelas VII MTs Paradigma Palembang. Sampel pada penelitian ini ialah kelas VIIB sebagai kelas eksperimen dan kelas VIIC sebagai kelas kontrol.

Teknik pengambilan sampel yang digunakan dalam penelitian ini ialah dengan metode purposive sampling.

\section{Prosedur Penelitian}

Pada Tahap Persiapan,

Melaksanakan analisis kebutuhan ke sekolah dengan wawancara bersama guru mata pelajaran IPA, wawancara bersama siswa siswa, meberikan angket kepada guru mata pelajaran IPA, memberikan angket kepada siswa, observasi, dan tes awal pemahaman konsep siswa.

Tahap Pelaksanaan, Pemberian tes awal (pretest) pada kedua kelas. Selanjutnya penyajian eksperimen dengan proses pembelajaran menggunakan model pembelajaran SainsTeknologi Masyarakat (STM) dikelas eksperimen, sedangkan di kelas kontrol dilakukan proses pembelajaran menggunakan model pembelajaran konvensional, kemudian pemberian tes akhir (posttest) pada kedua kelas sebagai pengumpulan data kemudian dilakukan uji akhir.

Tahap Akhir, Setelah tahap persiapan dan tahap pelaksanaan, tahap selanjutnya adalah tahap akhir yaitu dilaksanakan pengolahan data dan pembahasan data dari hasil penelitian serta pengambilan kesimpulan dari hasil penelitian yang telah dilaksanakan.

\section{Teknik Pengumpulan Data}

Teknik yang digunakan untuk pengambilan dan pengumpulan data dalam penelitian ini adalah observasi dan tes. Teknik pengumpulan data dengan observasi digunakan jika penelitian berkenaan dengan perilaku manusia, proses kerja dan gejala-gejala alam (Sugiyono, 2015). Dalam penelitian ini observasi keterlaksanaan model pembelajaran Sains Teknologi Masyaraka (STM) yang dilakukan guru dan siswa.Observasi keterlaksanaan model pembelajaran Sains Teknologi Masyaraka (STM) ini bertujuan untuk melihat apakah tahapan-tahapan model pembelajaran Sains Teknologi Masyaraka (STM) telah dilaksanakan oleh guru dan siswa atau tidak. Observasi ini dibuat dalam bentuk checklist.

Tes adalah penilaian yang komperhensif terhadap seorang individu atau keseluruhan usaha evaluasi program (Arikunto, 2010). Instrument tes yang 
digunakan ialah tes tertulis (paper and pencil test) yaitu berupa tes uraian dalam bentuk (soal pre-test sama dengan soal post-test). Jumlah total soal tes yang digunakan dalam penelitian ini ialah sebanyak 10 soal. Soal-soal tes yang diberikan merupakan soal tes yang dapat mengukur ketercapaian pemahaman konsep siswa berdasarkan taksonomi Bloom kategori memahami mencakup 7 indikator proses kognitif sebagai berikut, Menafsirkan (interprenting), Memberikan contoh (exemplifying), Mengklasifikasikan (classifying), Meringkas (summarizing), Menarik inferensi (inferring), Membandingkan (comparing) dan Menjelaskan (explaining).

\section{Uji Validitas}

Validitas adalah suatu ukuran yang menunjukkan tingkat kevalidan atau kesahihan suatu instrumen (Arikunto, 2009). Perhitungan validitas instrumen dengan menggunakan program SPSS 16.0.

Menurut Sujarweni (2015), dengan menggunakan jumlah peserta tes (n) maka nilai $r$ tabel dapat diperoleh melalui tabel $r$ product moment pearson dengan $\mathrm{df}$ $($ degree of freedom $)=\mathrm{n}-2$. Butir soal dapat dikatakan valid jika $\mathrm{r}$ hitung (Corrected Item Total Correlation) $>\mathrm{r}$ tabel. Berdasarkan hasil perhitungan validitas instrumen tes pemahaman konsep Ekosistem yang terdiri dari 33 item soal uraian, didapat 21 item soal dinyatakan valid, tetapi hanya diambil 10 soal yang digunakan.

\section{Uji Reliabilitas}

Reliabilitas artinya dapat dipercaya dan dapat diandalkan. Analisis realiabilitas dilakukan untuk mengetahui soal yang sudah disusun dapat memberikan hasil yang tetap atau tidak tetap (Arikunto, 2009). Perhitungan reliabilitas instrumen dengan menggunakan program SPSS 16.0.

Menurut Sujarweni (2015), uji reliabilitas dapat dilihat pada nilai Cronbach's Alpha, jika nilai Alpa > 0,60 maka butir soal yang merupakan dimensi variabel adalah reliabel. Berdasarkan hasil perhitungan reliabilitas tes didapat hasil Cronbach's Alpha $=0,835$ dari 21 butir soal yang valid. Hal ini dapat dinyatakan reliabel dan selanjutnya dapat digunakan dalam penelitian.

\section{Teknik Analisis Data}

Uji normalitas data dalam penelitian ini dilakukan dengan menggunakan uji Kolmogorov-Smirnow karena uji ini cocok untuk menganalisis data interval seperti skala pemahaman konsep siswa. Pengujian dilakukan pada masing-masing variabel dengan asumsi datanya berdistribusi normal.

Uji Statistik Kolmogorov-Smirnow (K-S) dihitung dengan bantuan paket program SPSS 16.0. Kriteria ujinya ialah terima $\mathrm{H}_{0}$, jika nilai $\mathrm{K}-\mathrm{S}$ lebih kecil dari $\mathrm{K}$ $\mathrm{S}$ tabel, atau jika $p$-value lebih besar dari $\alpha$. Menurut Sujarweni (2015), untuk mengetahui normal atau tidaknya suatu data dapat dilihat dari hasil "Asymp.Sig (2tailled)"pada program SPSS dengan taraf signifikansi $5 \%(0,05)$. Jika hasil sig. tersebut lebih besar dari 0,05 maka distribusi data normal $(\mathrm{p}>0,05)$. Adapun hasil signifikansi untuk "Asymp.Sig (2tailled)" semuanya lebih besar dari 0,05, maka data telah berdistribusi normal.

Uji homogenitas digunakan untuk mengetahui kesetaraan data atau kehomogenan data. Uji ini untuk mengetahui kehomogenan data tentang pretest-posttest pada kelas eksperimen dan kelas kontrol (Hasan, 2011). Uji homogenitas digunakan dengan bantuan program SPSS 16.0 dengan teknik Levene Statistic.

Menentukan nilai uji homogenitas: Jika nilai Signifikan $<0,05$, maka dikatan bahwa data tidak homogen Jika nilai Signifikan > 0,05, maka dikatan bahwa data homogen

Setelah diketahui varian kedua kelompok homogen, maka pengolahan data dilanjutkan dengan pengujian hipotesis dengan menggunakan uji-t. Uji-t dimaksudkan untuk mengetahui signifikansi perbedaan dua rata-rata (mean) yang berpasangan (Hasan, 2011). Uji hipotesis digunakan dengan bantuan program SPSS 16.0 dengan analisis Independent Sample T Test.

Pengambilan keputusan

Jika Sig t hitung $>0,05$ maka $\mathrm{H}_{0}$ diterima Jika Sig t hitung $<0,05$ maka $\mathrm{H}_{0}$ ditolak 


\section{HASIL DAN PEMBAHASAN}

Rata-rata nilai tes akhir (posttest) pemahaman konsep siswa di kelas eksperimen adalah 80,47 sedangkan di kelas kontrol 50,22. Ini secara kuantitatif bahwa kelompok dengan model pembelajaran STM memiliki rata-rata nilai lebih tinggi dibandingkan dengan kelompok model pembelajaran konvensional.

Tabel 1. Rata-rata Nilai Pemahaman Konsep Siswa di Kelas Eksperimen dan Kelas Kontrol

\begin{tabular}{lccccc}
\hline \multicolumn{1}{c}{ Kelas } & N & $\begin{array}{c}\text { Rata-rata } \\
\text { Pretest }\end{array}$ & $\begin{array}{c}\text { Rata-rata } \\
\text { Posttest }\end{array}$ & N-Gain & Kategori \\
\hline Eksperimen & 17 & 35,18 & 80,47 & 0,70 & Tinggi \\
Kontrol & 18 & 33,22 & 50,22 & 0,25 & Rendah \\
\hline
\end{tabular}

(Sumber: Dok Pribadi, 2017)

Perbandingan data hasil N-Gain kelas eksperimen dan kelas kontrol dapat dilihat pada Gambar berikutt ini:

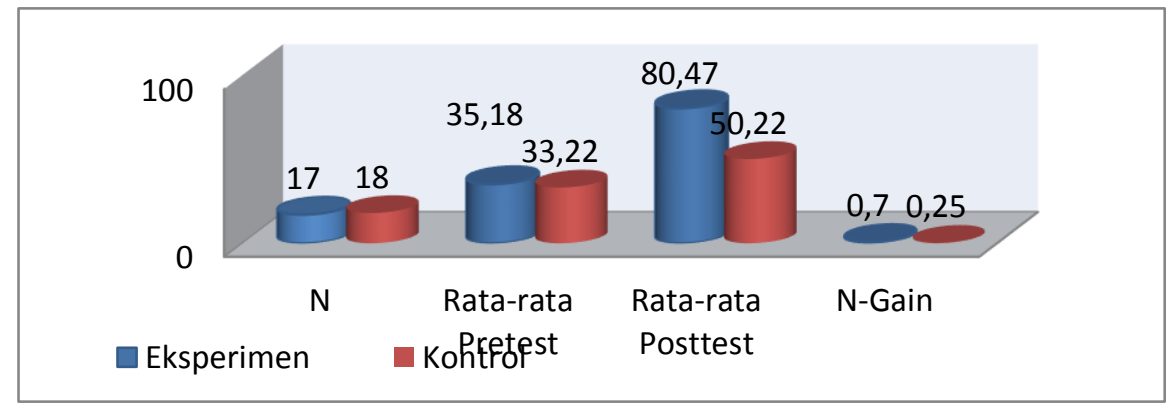

Gambar 1. Diagram Batang Nilai N-Gain

Kelas Eksperimen dan Kelas Kontrol (Sumber: Dok Pribadi, 2017)

$\begin{array}{ccr}\text { Selanjutnya, } & \text { sebelum menguji } \\ \text { apakah terdapat perbedaan antara }\end{array}$ pemahaman konsep siswa kelas eksperimen dan kelas kontrol, data hasil penelitian diuji melalui uji persyaratan analisis. Berdasarkan dua uji asumsi dasar yang telah dilakukan, dapat dilihat bahwa hasil uji normalitas dengan kolmogrovSmirnov menunjukkan semua data dalam penelitian ini terdistribusi normal. Hasil uji homogenitas varians dengan levene Statistic menunjukkan semua data berasal dari varian yang sama (homogen). Dengan terpenuhinya semua asumsi dasar tersebut, maka selanjutnya dapat dilakukan uji hipotesis melalui uji-t dengan Independent Sampel t test.

Sesuai dengan hasil pengujian hipotesis dengan uji-t, terbukti bahwa hipotesis alternatif $\left(\mathrm{H}_{\mathrm{a}}\right)$ yang diajukan secara signifikan dapat diterima. Hasil pengujian hipotesis menyimpulkan bahwa terdapat pengaruh model pembelajaran Sains Teknologi (STM) terhadap pemahaman konsep siswa pada pokok bahasan ekosistem, yang ditunjukkan dengan sig $t_{\text {hitung }} 0,000<0,05$. Hasil penelitian ini memberikan informasi khususnya kepada guru IPA bahwa model pembelajaran Sains Teknologi Masyarakat (STM) berpengaruh secara signifikan terhadap pemahaman konsep siswa.

Hal ini terbukti dengan terlihatnya peningkatan pemahaman konsep siswa dengan menggunakan model pembelajaran Sains Teknologi Masyarakat (STM), yang diperoleh dari nilai normal gain. Nilai ratarata masing kelas yaitu, untuk kelas eksperimen dengan gain 0,70 dengan kategori tinggi dan kelas kontrol 0,25 dengan kategori rendah. Berdasarkan nilai tersebut dapat diketahui bahwa kelas eksperimen memiliki $\mathrm{N}$-Gain lebih tinggi dibandingkan dengan kelas kontrol.

Sejalan dengan penelitian Smarabawa $d k k$ (2013), hasil penelitiannya menunjukkan bahwa 1) Pemahaman konsep biologi dengan Model 
Pembelajaran Sains Teknologi Masyarakat lebih baik daripada dengan Model Pembelajaran Langsung. 2) Keterampilan berpikir kreatif antara siswa yang belajar dengan Model Pembelajaran Sains Teknologi Masyarakat lebih baik dari pada dengan Model Pembelajaran Langsung.

Tabel 2. Persentase Peningkatan Pemahaman Konsep Siswa

\begin{tabular}{clcc}
\hline \multirow{2}{*}{ No } & \multirow{2}{*}{ Indikator } & \multicolumn{2}{c}{ ?ersentase Peningkatan Pemahaman Konsep (\%) } \\
\cline { 3 - 4 } & Menafsirkan & 23 & Kelas Eksperimen \\
\hline 1 & Memberikan contoh & 59 & 22 \\
2 & Mengklasifikasikan & 6 & 22 \\
3 & 59 & 6 \\
4 & Meringkas & 77 & 6 \\
5 & Menarik inferensi & 53 & 56 \\
6 & Membandingkan & 52 & 11 \\
7 & Menjelaskan & &
\end{tabular}

(Sumber: Dok Pribadi, 2017)

Untuk lebih mengetahui pemahaman konsep siswa, maka dilakukan analisis terhadap indikator-indikator pemahaman konsep.

Analisis peningkatan pemahaman konsep di kelas eksperimen, indikator menarik inferensi merupakan indikator yang mengalami peningkatan paling tinggi yaitu $77 \%$ dan indikator mengklasifikasikan merupakan indikator yang mengalami peningkatan paling rendah yaitu hanya $6 \%$ saja. Sedangkan analisis di kelas kontrol, indikator membandingkan merupakan indikator yang mengalai peningkatan paling tinggi yaitu $56 \%$ dan indikator menarik inferensi dan mengklasifikasikan merupakan indikator yang mengalami peningkatan paling rendah yaitu hanya $6 \%$ saja.

Berdasarkan analisis indikator yang telah dilaksanakan dapat diketahui bahwa setiap indikator pemahaman konsep siswa pada tes akhir (posttest) mengalami peningkatan dari tes awal (pretest) baik di kelas eksperimen maupun di kelas kontrol. Namun peningkatan pemahaman konsep di kelas eksperimen lebih tinggi daripada di kelas kontrol. Rata-rata persentase peningkatan pemahaman konsep di kelas eksperimen sebesar 48,2\% sedangkan di kelas kontrol sebesar 29,2\%. Hal ini sejalan dengan penelitian Aikenhead (2005), yang menyatakan bahwa siswa dengan pembelajaran Sains Teknologi Masyarakat tampak jelas menunjukkan pengaruh makin baik yang signifikan terhadap tes hasil belajar sains dibandingkan siswa dengan pembelajaran konvensional.

Perbandingan peningkatan persentase ketuntasan indikator pemahaman konsep di kelas eksperimen dan kelas kontrol dapat dilihat pada Gambar berikutt ini (\%):

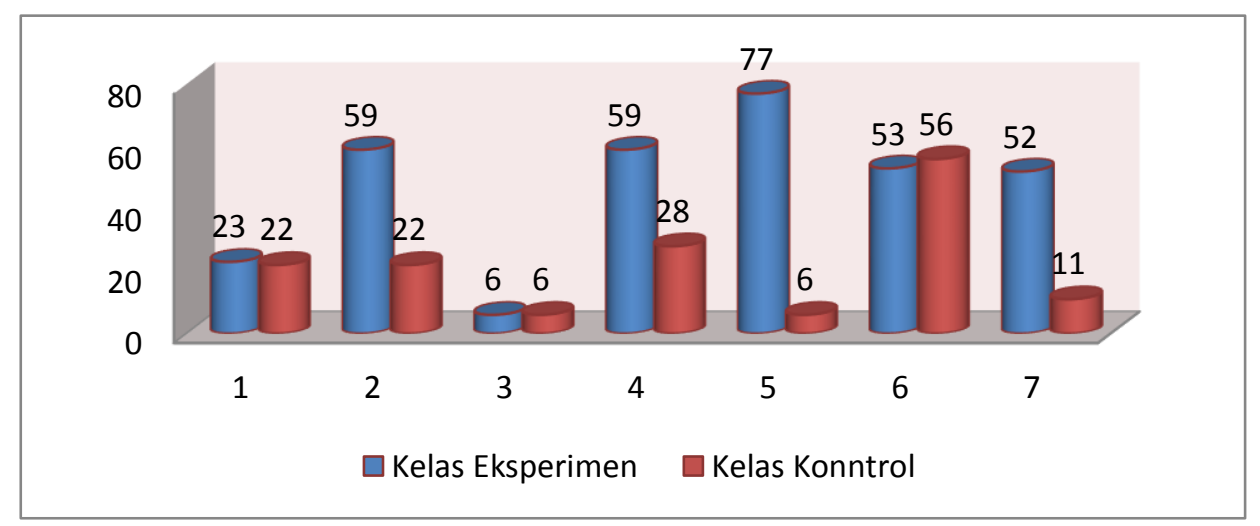

Gambar 2. Persentase Ketuntasan Indikator Pemahaman Konsep di Kelas Eksperimen dan Kelas Kontrol

(Sumber: Dok Pribadi, 2017) 
Untuk melihat hubungan antara model pembelajaran dengan pemahaman konsep siswa maka dilaksanakan observasi keterlaksanaan model yang diterapkan yaitu model pembelajaran Sains Teknologi Masyarakat (STM). Pengamatan dilakukan pada kegiatan guru dan kegiatan siswa.
Berdasarkan dilaksanakan berikut:

Tabe 3. Kegiatan Pembelajaran Model Sains Teknologi Masyarakat (STM) pada Kelas Eksperimen

\begin{tabular}{clcc}
\hline No & \multicolumn{1}{c}{ Tahap Model Pembelajaran STM } & Ada & Tidak Ada \\
\hline 1 & Invitasi & $\sqrt{ }$ & - \\
2 & Pembentukan Konsep & $\sqrt{ }$ & - \\
3 & Aplikasi Konsep & $\sqrt{ }$ & - \\
4 & Pemantapan Konsep & $\sqrt{ }$ & - \\
5 & Evaluasi & $\sqrt{ }$ & - \\
\hline
\end{tabular}

(Sumber: Dok Pribadi, 2017)

Dalam penelitian ini model pembelajaran STM yang digunakan adalah model pembelajaran yang dikembangkan oleh Poedjiadi (2010), dengan sintaks sebagai berikut, fase 1 (tahap invitasi); fase 2 (tahap pembentukan konsep); fase 3 (tahap aplikasi konsep atau penyelesaian masalah); fase 4 (tahap pemantapan konsep); fase 5 (tahap penilaian). Melalui sintaks model pembelajaran STM siswa dimungkinkan dapat menumbuhkan pemahaman konsep.

Model pembelajaran Sains Teknologi Masyarakat (STM) memberikan kesempatan kepada peserta didik dalam memahami materi. Hal ini berdasarkan pada karakteristik model pembelajaran Sains Teknologi Masyarakat (STM) yang memiliki tahapan secara sistematik untuk menuntut peserta didik mengkontruksi sendiri pengetahuan yang mereka dapatkan. Berdasarkan data hasil observasi yang telah diperoleh, dapat dilihat pada proses pembelajaran selama tiga kali pertemuan bahwa tahap-tahap dari model pembelajaran Sains Teknologi Masyarakat (STM) telah terlaksana.

Tahap pertama model pembelajaran Sains Teknologi Masyarakat (STM) yaitu invitasi, guru memberikan kesempatan kepada siswa untuk mengemukakan pendapat tentang kerusakan ekosistem sungai dan komponen apa saja penyusun ekosistem sungai? dan siswa mengemukakan pendapat mengenai masalah pada kehidupan nyata tersebut yang telah disajikan dalam LKS. Pada tahap ini indikator pemahaman konsep yang muncul yaitu indikator menjelaskan (explaining) dan indikator memberikan contoh (exemplifying). Siswa berusaha menjelaskan tentang kerusakan ekosistem sungai dan siswa berusaha memberikan contoh komponen ekosistem apa saja yang hidup di di dalam sungai.

Pada tahap ini siswa dituntut untuk berpikir secara kreatif mengemukakan isuisu sains yang diungkapkan, serta menganalisis keterkaitan dengan materi yang diajarkan. Pada model pembelajaran STM sangat mempertimbangkan pengetahuan awal siswa dan memberikan peluang bagi siswa untuk mengungkap atau menjelaskan gagasan-gagasannya. Menurut Poedjiadi (2010), pengetahuan awal merupakan pengetahuan, keterampilan dan kemampuan yang dibawa oleh siswa ke dalam proses pembelajaran. Gagasan siswa merupakan pengetahuan pribadi yang dibangun melalui proses informal dalam proses memahami pengalaman sehari-hari. Belajar bukan dipandang sebagai transmisi informasi atau pengisian bejana kosong, tetapi lebih sebagai suatu proses pengkontruksian aktif 
pada basis konsepsi-konsepsi yang telah ada yaitu berupa pengetahuan awal siswa.

Tahap kedua pembentukan konsep, pada pertemuan pertama guru mengarahkan siswa untuk mendefinisikan pengertian ekosistem, mengarahkan siswa untuk mengidentifikasi komponen abiotik dan biotik ekosistem, mengarahkan siswa untuk mengidentifikasi populasi dan komunitas dalam ekosistem dan pada pertemuan kedua guru mengarahkan siswa untuk mendeskripsikan hubungan antara komponen biotik dan abiotik, mengarahkan siswa untuk menggambar rantai makanan, jaring makanan dan piramida makanan dan mengarahkan siswa untuk menggambarkan pola interaksi mahluk hidup. Pada tahap ini indikator pemahaman konsep yang muncul yaitu, indikator menafsirkan (interprenting), memberikan contoh (exemplifying), mengklasifikasikan (classifying), membandingkan (comparing) dan menjelaskan (explaining). Karena pada tahap ini siswa berusaha menafsirkan gambar rantai makanan, jaringan makanan dan piramida makana. Siswa berusaha memberikan contoh komponen penyusun ekosistem dalam beberapa macam ekosistem yang disajikan dalam LKS dan berusaha memberikan contoh satuan dalam ekosistem. Siswa berusaha membandingkan dan mengklasifikasikan komponen abiotik dan komponen biotik ekosistem. Siswa berusaha menjelaskan hubungan antara konmponen ekosistem dan pola interaksi dalam ekosistem.

Pada tahap ini siswa berusaha memahami pemaparan tentang materi pembelajaran yang di sajikan dalam LKS dan literatur lainnya. Menurut pandangan konstruktivisme bahwasannya keterlibatan aktif siswa dalam pembelajaran menjadi titik tolak penting dalam mengkonstruksi pemahaman. Hal ini sejalan dengan penelitian Agustini dkk (2013) yang menyatakan bahwa siswa yang dituntut untuk terlibat aktif dalam pembelajaran dapat mengembangkan pemahaman materi sehingga dapat meningkatkan penguasaan konsep.

Tahap ketiga aplikasi konsep, guru membimbimbing siswa untuk menggunakan konsep tentang hubungan antara komponen abiotik dan komponen biotik dalam ekosistem. Guru membimbing siswa untuk membuat produk sederhana, dan dengan bimbingan guru siswa membuat filter air sederhana bersama kelompok. Pada tahap ini indikator pemahaman konsep yang muncul yaitu menjelaskan (explaining), siswa berusaha menjelaskan hubungan antara komponen abiotik dan komponen biotik ekosistem yang saling mempengaruhi. Pemahaman konsep pada tahap ini membentuk siswa dalam mengatur dan mensintesis informasi yang mereka kembangkan dalam kehidupan sehari-hari.

STM merupakan suatu inovasi pembelajaran yang dirancang untuk membantu siswa memahami teori secara mendalam melalui pengalaman belajar praktik empirik serta dapat mengaplikasikannya ke dalam teknologi. Kegiatan pembelajaran yang seperti ini tentunya lebih membuat siswa bergairah dan termotivasi untuk belajar. Hal ini sejalan dengan pendapat Slameto (2003), motivasi yang kuat sangat diperlukan dalam belajar karena dapat lebih mendorong siswa agar dapt belajar dengan baik, dengan berpikir dan memusatkan perhatian, merencanakan dan melaksanakan kegiatan yang menunjang belajar.

Tahap keempat model pembelajaran Sains Teknologi Masyarakat yaitu pemantapan konsep, guru meluruskan kesalahan dan pemahaman serta memberikan penguatan pada materi yang sedang dipelajari dan siswa mendengarkan penjelasan guru serta mengoreksi pemahaman yang salah. Pada tahap ini indikator pemahaman konsep yang muncul yaitu indikator meringkas (summarizing) dan indikator menarik inferensi (inferring). Siswa berusaha meringkas poin-poin umum yang dijelaskan guru dan siswa berusaha menarik kesimpulan dari pembelajaran yang telah dipelajari.

Pada sintaks model pembelajaran Sains Teknologi Masyarakat fase keempat ini, guru meluruskan jika kemungkinan ada miskonsepsi selama kegiatan belajar berlangsung, karena konsep-konsep kunci yang ditekanan pada akhir pembelajaran 
akan memiliki retensi lebih lama dibanding dengan jika tidak dimantapkan atau ditekankan oleh guru pada akhir pembelajaran. Hal ini sejalan dengan penelitian Walid (2011) yang menyatakan bahwa salah satu faktor yang mempengaruhi pemahaman konsep yaitu umpan balik, yang dapat menyediakan informasi terhadap kebenaran atau kesalahan hipotesis yang digunakan individu.

Tahap kelima evaluasi, guru memerintahkan siswa untuk menyimpan semua buku, lalu guru meminta siswa menjawab soal posttest untuk mengukur pemahaman konsep siswa yang meliputi indikator pemahaman konsep yaitu menafsirkan (interprenting), memberikan contoh (exemplifying), mengklasifikasikan (classifying), meringkas (summarizing), menarik inferensi (inferring), membandingkan (comparing) dan menjelaskan (explaining). Berdasarkan alur sintaknya, model pembelajaran Sains Teknologi Masyarakat (STM) memiliki pengaruh yang baik dalam meningkatkan pemahaman konsep siswa. 


\section{KESIMPULAN}

Berdasarkan hasil penelitian dapat disimpulkan bahwa penerapan model pembelajaran Sains Teknologi Masyarakat (STM) berpengaruh secara signifikan terhadap kemampuan pemahaman konsep siswa. Hasil uji-t data posttest menunjukkan bahwa sig thitung $=0,000<$ 0,05. Nilai N-Gain menunjukkan kemampuan pemahaman konsep lebih tinggi di kelas eksperimen 0,70 termasuk kategori tinggi, sedangkan kelas kontrol termasuk kategori rendah dengan nilai $\mathrm{N}$ Gain 0,25.

\section{DAFTAR PUSTAKA}

[1] Agustini, D., Subagia, I. W., Suardana, I. N. (2013). Pengaruh Model Pembelajaran Sains Teknologi Masyarakat (STM) terhadap Penguasaan Materi dan Keterampilan Pemecahan Masalah Siswa pada Mata Pelajaran IPA di MTs. Negeri Patas. E-Journal Program Pascasarjana Universitas Pendidikan Ganesha Program Studi Pendidikan Sains. Volume 3.

[2] Aikenhead, G. S. (2005). Research into STS Science Education. Education Quimica. No. 16.

[3] Al-Tabany, T. I. B. (2015). Mendesain Model Pembelajaran Inovatif, Progresif, dan Kontekstual. Jakarta: Prenadamedia Group.

[4] Anderson, L. W., Krathwohl, D. R. (2015). Kerangka Landasan untuk Pembelajaran, Pengajaran dan Asesmen. Yogyakarta: Pustaka Pelajar.

[5] Arikunto, S. (2009). Manajemen Penelitian. Jakarta: Rineka Cipta.

[6] _, S. (2010). Manajemen Penelitian. Jakarta: Rineka Cipta.

[7] Hasan, I. D. (2011). Pokok-pokok Materi Statistik I Edisi 5. Jakarta: PT Bumi Aksara.

[8] Hasbullah. (2013). Dasar-Dasar Pendidikan. Jakarta: Rajawali Perss.
[9] Mukminan. (2014). Tantangan Pendidikan Abad 21. Makalah Seminar Nasional Teknologi Pendidikan Universitas Negeri Surabaya.

[10] Poedjiadi, A. (2010). Sains Teknologi Masyarakat. Bandung: PT Remaja Rosdakarya.

[11] Samarabawa. Arnyana. Setiawan. (2013). Pengaruh Model Pembelajaran Sains Teknologi Masyarakat terhadap Pemahaman Konsep Biologi dan Keterampilan Berpikir Kreatif Siswa SMA. EJournal Program Pascasarjana Universitas Pendidikan Ganesha Program Studi IPA. Vol 3.

[12] Slameto. (2003). Belajar dan FaktorFaktor yang Mempengaruhinya. Jakarta: Rineka Cipta.

[13] Septiawan. Arini. Sudatha, W. (2014). Penerapan Model Pembelajaran Sains Teknologi Masyarakat (STM) Berbantuan Media Audio Visual untuk Meningkatkan Hasil Belajar IPA pada Siswa Kelas V Semester Ganjil di SD Negeri 2 Sudaji, Kecamatan Sawan, Kabupaten Buleleng Tahun Pelajaran 2013/2014. Jurnal Mimbar PGSD Universitas Pendidikan Ganesha Jurusan PGSD. Vol 2. No 1.

[14] Sugiyono. 2015. Metode Penelitian Kombinasi (Mixed Methods). Bandung: Alfabeta.

[15] Sujarweni, V. W. (2015). SPSS untuk Penelitian. Yogyakarta: Pustaka Baru Press.

[16] Walid, M. F. (2011). Kemampuan Siswa dalam Memahami Konsep Materi dan Perubahan dalam Pembelajaran Kimia Materi Pokok Hukum-Hukum Dasar Kimia Studi pada Siswa Kelas X Semester I SMK Askhabul Kahfi Semarang, dalam htt p://library.walisongo.ac.id/digilib/do wnload.php?id=20596. Diakses 05 Desember 2016. 
[17] Yager, R. E. (1992). The Status of Science - Technology - Society Reform Efforts around the World. International Council of Assoclations for Science Education. Icase Yearbook 